\title{
PERTUMBUHAN DAN SINTASAN CACING LAUT Nereis sp. (POLYCHAETA, ANNELIDA) YANG DIBERI JENIS PAKAN BERBEDA
}

\author{
Rasidi*) dan Mufti P. Patria**) \\ ) Pusat Penelitian dan Pengembangan Perikanan Budidaya \\ Jl. Ragunan 20, Pasar Minggu, Jakarta Selatan 12540 \\ E-mail: rasidi_clp@yahoo.com \\ *) Departemen Biologi Fakultas Matematika dan Ilmu Pengetahuan Alam \\ Universitas Indonesia, Depok
}

(Naskah diterima: 17 Juli 2012; Disetujui publikasi: 12 Oktober 2012)

\begin{abstract}
ABSTRAK
Cacing laut sebagai pakan berkualitas tinggi sangat dibutuhkan dalam proses pematangan gonad dan pemijahan udang dan ikan. Namun informasi bahan pakan lokal alternatif untuk budidayanya masih terbatas. Tujuan penelitian ini adalah untuk mengetahui potensi beberapa bahan baku lokal sebagai alternatif pakan dalam budidaya cacing laut Nereis sp. Metode penelitian menggunakan metode eksperimental dengan random design. Rancangan percobaan menggunakan Rancangan Acak Lengkap (RAL) dengan 4 perlakuan dan 6 ulangan. Perlakuan yang diberikan pada pemeliharaan Nereis sp. dengan menggunakan perbedaan jenis pakan. Pakan yang digunakan terdiri atas 4 jenis: (A) tepung usus ayam broiler, (B) tepung kepala udang, (C) tepung darah ayam, dan (D) pakan komersial (kontrol). Hasil penelitian menunjukkan pertambahan bobot berkisar 0,31-1,01 g, dan laju pertumbuhan spesifik berkisar 0,73\%-1,76\%/hari, serta tingkat sintasan berkisar $80,56 \%-92,22 \%$. Hasil analisis varian terhadap pertumbuhan, laju pertumbuhan spesifik, dan sintasan berbeda nyata (anova $\mathrm{P}<0,05$ ). Perlakuan terbaik diperoleh pada pakan dari tepung usus ayam broiler. Jenis pakan yang lain juga mempunyai kualitas yang sama dengan pakan komersial. Dengan demikian tepung usus ayam, kepala udang, dan tepung darah dapat digunakan sebagai alternatif pakan dalam budidaya cacing laut selain pakan ikan komersial.
\end{abstract}

KATA KUNCl: Nereis sp. budidaya, pakan, pertumbuhan, dan sintasan

ABSTRACT: Growth and survival rate marine worm Nereis sp. (Polychaeta, Annelida) with difference feeds. By: Rasidi and Mufti P. Patria

Marine worms are known as highly nutritions feed ingredient for gonad maturation and induce spawning. On the other hand, information regarding alternatif feed ingredients to culture the worms is limited. The present study aimed to find the local waste material for feed marine worm. The eficiency of local waste material as alternative feed for marine worm culture. The experiment was done by random design with 4 treatments and 6 replications. Experimental unit were arranged in a completely randomized design. The treatment were: (A) intestine chicken powder, (B) shrimp head powder, (C) chicken blood powder, and (D) commercial fish feed as control. The initial weight of worms were ranged between 0.67-0.71 g. After 50 days of culture, the result shown that weight gain was ranged between 0.31-1.01 g, spesific growth rate (SGR) was 0.73\%-1.76\%/day, and survival rate was $80.56 \%-92.22 \%$. Based on analysis of varian for growth, spesific growth rate, and survival rate showed significant different. 
The best treatment was intestine chicken powder compared to the other treatments. The conclusion of this research that was the feed from local waste material can be used as alternative feed for marine worm culture to replace or substitute commercial feed.

KEYWORDS: Nereis sp., culture, feed, growth, and survival rate

\section{PENDAHULUAN}

Cacing laut atau nama ilmiahnya Polychaeta mempunyai nilai manfaat yang penting sebagai pakan untuk induk udang (Olive, 1999), dan ikan hias laut (Ignatius, 2001) terutama dalam proses pematangan gonad dan pemijahan (Wouters et al., 2001; Coman et al., 2007). Jenis-jenis Polychaeta yang banyak dimanfaatkan termasuk famili Nereididae dan Eunicidae (Brown et al., 2011). Cacing Polychaeta Nereis sp. merupakan salah satu jenis yang termasuk famili Nereididae, yang digunakan sebagai pakan induk di pembenihan udang (Costa et al., 2000).

Pemanfaatan cacing laut atau Polychaeta sebagai pakan induk beberapa spesies udang dan ikan laut telah banyak diteliti. Coman et al. (2007) telah menggunakan perbedaan komposisi cumi-cumi dan kerang yang dicampur dengan 5\% Polychaeta Marphysa sp. sebagai pakan induk udang windu (Peneaus monodon) untuk proses pemijahan. Hasilnya diperoleh informasi komposisi ketiga jenis pakan alami tersebut berpengaruh terhadap pematangan gonad induk udang, hal ini disebabkan kandungan asam amino dan asam lemak yang tinggi yang diperlukan dalam metabolisme dan siklus reproduksi udang penaeid (Wouters et al., 2001). Meunpol et al. (2005) melakukan penelitian terhadap induk udang windu jantan yang diberi pakan komersial dan beberapa jenis pakan alami, diperoleh informasi pakan alami dan kombinasi kedua jenis pakan tersebut merupakan pakan yang terbaik. Hal ini disebabkan kandungan asam lemak esensial terutama arachidonic acid (ARA), eicosapentaenoic acid (EPA) dan docosahexaenoic acid (DHA) yang berperan dalam merangsang pematangan gonad induk udang (Kian et al., 2004; Meunpol et al., 2005). Selanjutnya Nguyen et al. (2009) menggunakan cacing laut sebesar 7,66\% dan 16,50\% sebagai pakan induk udang windu, yang menghasilkan frekuensi pemijahan dan fekunditas yang berbeda nyata dengan pakan yang mengandung komposisi cacing laut lebih kecil. Kesuksesan ini disebabkan kandungan
ARA/EPA dan DHA/EPA dalam cacing laut berperan penting dalam memacu pematangan gonad induk udang. Nguyen et al. (2011) juga telah menggunakan tiga jenis ekstrak dari Polychaeta sebesar 0,5\% lemak netral untuk pakan induk udang Marsupenaeus japonicas yang menunjukkan ekstrak Polychaeta terutama lemak netral berperan dalam proses pemijahan induk udang windu dibandingkan fraksi yang lain. Selain itu kandungan hormon steroid pada Polychaeta juga tinggi yang berperan dalam proses vitelogenesis induk udang (Meunpoul, 2007). Berdasarkan hasil penelitian terdahulu mengenai pemanfaatan Polychaeta sebagai pakan induk udang menunjukkan Polychaeta mampu memenuhi kebutuhan nutrisi esensial yang dibutuhkan induk udang yang tidak dapat diproduksi sendiri, sehingga harus dipenuhi dari pakan alami (Woters et al., 2001; Yuwono, 2005).

Selain pada udang, cacing Polychaeta juga dapat dimanfaatkan sebagai pakan induk ikan hias laut. Ignatius et al. (2001) juga telah melakukan penelitian dengan menggunakan dua jenis pakan yaitu pakan yang dicampur dan tidak dicampur Polychaeta sebagai pakan induk ikan hias clown fish (Amphiprion sebae). Induk ikan hias tersebut diberi pakan yang mengandung Polychaeta mempunyai tingkat pematangan gonad yang lebih cepat dibandingkan dengan pakan yang lain, sedangkan induk ikan hias clown fish yang tanpa diberi Polychaeta tidak memijah. Hal ini disebabkan kandungan asam lemak esensial yang lebih tinggi dibandingkan jenis pakan yang lain yang dapat merangsang pematangan gonad. Berdasarkan hasil penelitian-penelitian tersebut menunjukkan cacing laut berperan penting dalam proses bioreproduksi induk udang maupun ikan. Terutama kandungan asam lemak tak jenuh tinggi/Highly Unsaturated Fatty Acids (HUFA) yang dapat merangsang proses pematangan gonad crustacea dan ikan-ikan laut (Brown et al., 201 1; Wouters et al., 2001).

Penelitian budidaya cacing laut terdahulu yang sudah dilakukan antara lain oleh Batista 
et al. (2003) yang menggunakan pakan komersial ikan Sea bream (Sparus auratus) dan pakan ikan hias menghasilkan pertumbuhan yang sama. Costa et al. (2000), telah menggunakan 6 jenis pakan yaitu lancy (pakan untuk udang stadia post larva udang), Tetramin, SBDF (pakan ikan sea bream), sari kedelai, pollen, dan kista artemia). Berdasarkan hasil penelitian tersebut diperoleh informasi laju pertumbuhan berkisar 6,2-13,9 mg/hari dan sintasan berkisar $77,7 \%-100 \%$, perlakuan terbaik diperoleh pada perlakuan yang menggunakan jenis lancy. Dengan demikian, pakan komersial untuk ikan dan udang juga dapat dimanfaatkan sebagai pakan cacing laut.

Kebutuhan nutrisi cacing laut dapat dipenuhi dengan menggunakan pakan komersial yang biasa digunakan untuk ikan dan udang (Batista et al., 2003; Costa et al., 2000). Tetapi dalam pelaksanaannya penggunaan pakan komersial yang terus-menerus menimbulkan permasalahan baru, hal ini dikarenakan harga pakan komersial pabrikan yang semakin mahal. Di samping itu, kegiatan budidaya memerlukan biaya terbesar untuk pengadaan pakan sehingga akan memperbesar biaya operasional. Oleh sebab itu, diperlukan bahan baku yang dapat dijadikan alternatif pakan selain pakan komersial.

Bahan baku pakan dapat diperoleh dengan memanfaatkan limbah-limbah dari kegiatan masyarakat. Beberapa penelitian telah dilakukan dengan memanfaatkan limbah pakan dari kegiatan budidaya ikan. Kegiatan budidaya ikan dapat dikombinasikan dengan budidaya cacing laut yaitu dengan memanfaatkan sisa pakan yang tidak dimakan ikan sebagai pakan cacing Nereis diversicolor (Bischoff et al., 2009) dan Nereis virens (Brown et al., 2011).

Salah satu alternatif yang dapat digunakan sebagai pakan dalam budidaya cacing laut dengan menggunakan pakan yang berasal dari hewan. Wibowo (2010), melaporkan bahwa telah diketahui pakan dengan kandungan protein hewani menghasilkan pertumbuhan Dendronereis pinaticirris terbaik. Yuwono et al. (2000) melaporkan bahwa kompos dari feses hewan sebagai media dalam pemeliharaan cacing lur yang menghasilkan pertumbuhan yang lebih baik dibandingkan dengan penggunaan kompos dari serasah tumbuhan. Berdasarkan hasil penelitian tersebut bahan baku pakan berasal dari hewani mempunyai kualitas lebih baik dibandingkan bahan dari nabati.
Beberapa jenis limbah sebagai bahan hewani yang potensial tersedia di Indonesia dengan memanfaatkan produk sampingan dari rumah pemotongan ayam berupa usus besar, darah ayam, dan dari industri pengolahan udang berupa cangkang kepala udang. Pemilihan bahan baku ini didasarkan pada nilai nutrisi yang cukup, harganya relatif murah, dan ketersediaan di masyarakat sebagai limbah. Penggunaan bahan-bahan tersebut sebagai bahan pakan kegiatan budidaya cacing laut merupakan salah satu bentuk pemanfaatan limbah.

Usus besar dan darah ayam merupakan produk sampingan dari peternakan (poultry by product), sedangkan kepala udang merupakan limbah dari industri pengolahan udang. Berdasarkan kandungan nutrisinya bahanbahan tersebut mempunyai kandungan nutrisi yang cukup tinggi. Beberapa penelitian pemanfaatan limbah sebagai pakan ikan yang telah dilakukan antara lain Rachmansyah et al. (2006) menggunakan pakan komersial yang mengandung tepung usus ayam 5\%-20\% mempunyai kadar protein sebesar $44,62 \%$ $45,81 \%$ dan dapat menggantikan peran tepung ikan dalam pakan sebanyak $20 \%$ atau setara dengan $39 \%$ protein tepung ikan untuk budidaya ikan kerapu di keramba jaring apung.

Penggunaan tepung darah juga potensial sebagai salah satu alternatif pakan pada budidaya ikan sebagai pengganti tepung ikan (Wilding et al., 2006). Kandungan nutrisi tepung darah meliputi protein sebesar $71,45 \%$; lemak 0,42\%; karbohidrat 13,12\%; serat 7,95\%; dan air $5,19 \%$. Penggunaan tepung darah sebesar $25 \%$ dalam formulasi pakan sebagai pengganti tepung ikan menghasilkan pertumbuhan terbaik pada yuwana ikan lele Clarias gariepinus (Agbebi et al., 2009).

Penggunaan tepung kepala udang untuk campuran pakan yuwana udang Litopenaeus schmitti menunjukkan pertumbuhan yang signifikan dibandingkan dengan yang tidak menggunakan tepung kepala udang (JaimeCeballos et al., 2009). Sudaryono et al. (1995) menggunakan tepung kepala udang dengan kadar protein $58,27 \%$ dan lemak 4,89\% (dry weight) sebagai pakan yuwana udang windu menghasilkan pertumbuhan yang berbeda nyata dengan pakan yang tidak mengandung tepung kepala udang. Pemanfaatan tepung darah dan usus ayam serta tepung kepala udang telah dilakukan pada beberapa jenis ikan dan udang dengan hasil yang signifikan. 
Namun pemanfaatan bahan-bahan tersebut sebagai alternatif pakan pada budidaya cacing laut belum pernah dilakukan.

Menurut Costa et al. (2000) cacing N. diversicolor merupakan cacing laut yang bersifat omnivora, deposit feeder dan dapat memanfaatkan pakan tunggal yang diberikan sebagai sumber energi untuk pertumbuhan dan sintasannya. Penelitian ini bertujuan untuk mengetahui potensi pemanfaatan beberapa jenis pakan berbeda (tepung darah dan usus ayam serta tepung kepala udang) sebagai pakan dalam budidaya cacing laut. Untuk memenuhi tujuan tersebut diperlukan penelitian eksperimental skala laboratorium mengenai pengaruh perbedaan beberapa jenis pakan berbeda tersebut terhadap pertumbuhan dan sintasan Nereis sp. Manfaat dari penelitian ini adalah diperolehnya data dan informasi jenis pakan terbaik dari penggunaan beberapa jenis pakan yang berbeda, yang dapat digunakan sebagai alternatif pakan selain pakan komersial yang dapat digunakan dalam budidaya cacing laut.

\section{BAHAN DAN METODE}

Penelitian dilakukan di Laboratorium Pusat Penelitian dan Pengembangan Perikanan Budidaya, Jakarta. Pemeliharaan cacing di laboratorium dilakukan selama 50 hari.

Bahan-bahan yang digunakan dalam penelitian ini antara lain cacing Nereis sp., lumpur mangrove, air laut, dan air tawar. Bahan pakan terdiri atas usus besar dan darah ayam broiler, cangkang kepala udang, serta pakan komersial untuk ikan hias merk Master. Alat-alat yang digunakan dalam penelitian ini bak plastik (ukuran $33 \mathrm{~cm} \times 24 \mathrm{~cm} \times 12 \mathrm{~cm}$ ), aerator, timbangan digital dengan ketelitian $0,01 \mathrm{~g}$, dan alat ukur kualitas air multiparameter.

Metode yang digunakan mengacu Costa et al. (2000) yang dimodifikasi. Rancangan percobaan yang digunakan menggunakan metode ekperimental dengan Rancangan Acak Lengkap. Pemeliharaan cacing Nereis sp. dengan 4 (empat) jenis perlakuan dan 6 kali ulangan. Perlakuan yang diberikan terdiri atas: $A=$ pakan berupa tepung usus ayam broiler, $\mathrm{B}=$ pakan berupa tepung kepala udang, $\mathrm{C}=$ pakan berupa tepung darah ayam, dan $\mathrm{D}=$ pakan komersial (kontrol).

Parameter utama dalam penelitian ini adalah sintasan, pertumbuhan bobot (g) dan kandungan nutrisinya. Untuk mengetahui kom- posisi substrat media pemeliharaan dilakukan analisis substrat di laboratorium. Untuk memantau kestabilan kualitas fisika dan kimia air (suhu, salinitas, DO, dan $\mathrm{pH}$ ) diukur menggunakan alat ukur kualitas air multiparameter.

\section{Cara Kerja}

\section{Persiapan pakan uji}

Persiapan pembuatan tepung dari bahanbahan yang akan digunakan dalam penelitian ini antara lain cangkang kepala udang, dan usus besar dan darah ayam broiler. Bahanbahan tersebut dibersihkan kemudian dijemur sampai kering, dan di-oven kemudian digiling dengan blender sampai menjadi tepung. Untuk mengetahui kandungan nutrisinya kemudian dilakukan analisis proksimat di Laboratorium Akuakultur, Fakultas Perikanan dan IImu Kelautan, Institut Pertanian Bogor.

\section{Persiapan media dan tempat penelitian}

Media pemeliharaan cacing berupa lumpur mangrove yang diambil dari Serang-Banten. Sebagian lumpur dianalisis komposisi substrat di Laboratorium Proling Fakultas Perikanan dan Ilmu Kelautan, Institut Pertanian Bogor. Lumpur dibersihkan dari serasah dan sampah lainnya kemudian dimasukkan ke wadah percobaan (ukuran $33 \mathrm{~cm} \times 24 \mathrm{~cm} \times 12 \mathrm{~cm}$ ). Ketebalan lumpur $4 \mathrm{~cm}$, kemudian diberi air setinggi 3 $\mathrm{cm}$ dari permukaan lumpur dengan salinitas $15 \%$ serta diaerasi dibiarkan selama seminggu (Yuwono et al., 2000; Wibowo, 2010).

\section{Penempatan cacing uji}

Cacing diambil dari Desa Kemayungan, Serang-Banten dengan menggunakan tangan. Cacing kemudian dibersihkan dari kotoran. Kemudian cacing diseleksi dan diaklimatisasi dengan dengan ditempatkan dalam air laut yang diberi aerator selama satu malam. Pada hari berikutnya dilakukan penimbangan bobot awal. Masing-masing wadah diisi cacing dengan kepadatan 30 ekor/wadah. Selanjutnya dibiarkan selama seminggu untuk adaptasi terhadap media dan lingkungan baru.

\section{Pemberian pakan uji}

Pakan uji sesuai dengan perlakuan diberikan setiap 2 hari sekali. Jumlah pakan yang diberikan sebanyak 3\% dari total biomassa cacing per wadah penelitian (Safarik et al., 2006). 


\section{Parameter yang diukur}

Parameter yang diukur selama penelitian antara lain: jumlah, bobot cacing pada awal dan akhir penelitian, jumlah pakan yang diberikan, hasil analisis proksimat cacing penelitian. Untuk memantau kestabilan media uji, parameter kualitas air (salinitas, suhu, DO, dan $\mathrm{pH}$ ) diukur setiap minggu.

\section{Variabel Penelitian}

Variabel penelitian berupa sintasan, pertambahan bobot, laju pertumbuhan spesifik, dan konversi pakan.

\section{Sintasan}

Pengamatan sintasan cacing dilakukan dengan menghitung jumlah cacing yang hidup pada akhir penelitian dibandingkan dengan jumlah awal penelitian.

$\mathrm{S}=\mathrm{Nt} /$ No $\times 100 \% \quad$ (Hariyadi \& Yuwono, 1998)

di mana:

$S=$ Sintasan

$\mathrm{Nt}=$ Jumlah cacing pada akhir penelitian

No $=$ Jumlah cacing pada awal penelitian

\section{Pertumbuhan}

\section{Pertumbuhan mutlak}

Pengukuran bobot badan cacing dilakukan penimbangan dan pengukuran pada awal dan akhir penelitian, dihitung berdasarkan Hariyadi \& Yuwono (1998):

$$
\text { Pertambahan Bobot }=\mathrm{Bt}-\mathrm{Bo}
$$

di mana:

$\mathrm{Bt}=$ Bobot rata-rata cacing pada akhir penelitian Bo $=$ Bobot rata-rata cacing pada awal penelitian

\section{Laju pertumbuhan spesifik (Spesifik Growth Rate)}

Penghitungan laju pertumbuhan spesifik berdasarkan Batista et al. (2003) yaitu:

$$
\mathrm{SGR}=\frac{\ln W \mathrm{t}-\operatorname{Ln} \mathrm{Wo}_{\mathrm{o}}}{\mathrm{t}} \times 100 \%
$$

di mana:

$\mathrm{SGR}=$ Laju pertumbuhan spesifik (Spesific growth rate) (\%)

Wt = Bobot rata-rata cacing pada akhir penelitian $(\mathrm{g})$
Wo = Bobot rata-rata cacing pada awal penelitian (g)

$\mathrm{t} \quad=$ Waktu penelitian (hari)

\section{Hubungan panjang-bobot}

Untuk mengetahui pola pertumbuhan menggunakan rumus $\mathrm{W}=\mathrm{aL}^{\mathrm{b}}$ (Efendi, 1979).

\section{Konversi pakan}

Konversi pakan merupakan bilangan yang menyatakan jumlah pakan yang diberikan terhadap pertambahan bobot hewan uji. Konversi pakan dihitung berdasarkan rumus:

$$
\mathrm{FCR}=\frac{\mathrm{F}}{\mathrm{Wt}-\mathrm{Wo}}
$$

di mana:

FCR $=$ Konversi pakan (Feed conversion ratio)

$\mathrm{F}=$ Jumlah pakan total selama penelitian (g)

$\mathrm{Wt}=$ Bobot total cacing pada akhir penelitian ( $\mathrm{g}$ )

Wo = Bobot total cacing pada awal penelitian $(\mathrm{g})$

\section{Analisis Data}

Data pengamatan berupa sintasan, pertumbuhan, laju pertumbuhan, konversi pakan, dan hasil analisis proksimat cacing dianalisis menggunakan ANOVA dengan tingkat kepercayaan $95 \%$. Apabila ada perbedaan dilanjutkan uji Beda Nyata Terkecil atau Lower Significance Diferent. Untuk mengetahui hubungan antar variabel dependen dan independen menggunakan analisis korelasi Pearson's. Analisis dilakukan dengan menggunakan software program SPSS versi 16 .

\section{HASIL DAN BAHASAN}

\section{Hasil}

Penelitian dilakukan selama 50 hari di laboratorium. Hasil penelitian diperoleh data kandungan nutrisi pakan uji, sintasan, pertumbuhan, laju pertumbuhan spesifik, hubungan panjang-bobot, dan konversi pakan. Masingmasing data hasil penelitian disajikan secara rinci sebagai berikut.

\section{Kandungan nutrisi pakan uji}

Jenis pakan yang digunakan sebagai pakan uji dalam penelitian ini terdiri atas 4 jenis yaitu: tepung usus ayam, tepung kepala udang, tepung darah ayam, dan pakan komersial (kontrol). Hasil analisis proksimat jenis pakan uji disajikan pada Tabel 1 . 
Tabel 1. Hasil analisis proksimat pakan uji yang digunakan selama penelitian

Table 1. Result of proximate analysis of feed used in the experiment

\begin{tabular}{|c|c|c|c|c|c|c|}
\hline \multirow{2}{*}{$\begin{array}{l}\text { Parameter } \\
\text { Parameters }\end{array}$} & \multirow{2}{*}{$\begin{array}{l}\text { Satuan } \\
\text { Unit }\end{array}$} & \multicolumn{4}{|c|}{ Kode sampel (Sample code) } & \multirow{2}{*}{$\begin{array}{l}\text { Metode/alat } \\
\text { Method/tools }\end{array}$} \\
\hline & & A & B & C & D & \\
\hline \multicolumn{7}{|l|}{ Kimia: } \\
\hline Kadar air (Water content) & $\%$ & 5.87 & 24.39 & 15.90 & 8.57 & Gravimetri \\
\hline Kadar abu (Ash content) & $\%$ & 2.49 & 3.11 & 14.94 & 7.10 & Gravimetri \\
\hline Protein & $\%$ & 45.50 & 64.07 & 37.59 & 33.61 & Kjedahl/Titrasi \\
\hline Lemak (Lipid) & $\%$ & 35.63 & 0.41 & 10.47 & 3.07 & Soxlet Ekstraksi \\
\hline \multicolumn{7}{|l|}{ Karbohidrat (Carbohydrate) } \\
\hline Serat kasar (Crude fibre) & $\%$ & 0.84 & 0.00 & 18.96 & 2.31 & Gravimetri \\
\hline $\begin{array}{l}\text { Bahan ekstrak tanpa nitrogen (BETN) } \\
\text { Nitrogen free extract (NFE) }\end{array}$ & $\%$ & 9.67 & 8.02 & 2.14 & 45.34 & Perhitungan \\
\hline
\end{tabular}

Keterangan (Note):

A : Tepung usus ayam, B : Tepung kepala udang, C : Tepung darah ayam, D : Pakan komersial (kontrol) $A$ : Intestine chicken powder, $B$ : Shrimp head powder, C: Chicken blood powder, D : Commercial feed (control)

Berdasarkan Tabel 1 dapat diketahui kadar nutrisi masing-masing jenis pakan uji yang digunakan selama penelitian. Berdasarkan hasil analisis proksimat diketahui kadar protein berkisar 33,61\%-64,07\%. Kadar protein terendah diperoleh pada pakan D (pakan komersial) diikuti pakan A (tepung usus ayam), $C$ (tepung darah) sedangkan tertinggi pada pakan B (tepung kepala udang). Kadar lemak berkisar 0,41\%-35,63\% (bobot basah), kadar lemak terendah diperoleh pada pakan B (tepung kepala udang) diikuti C dan D, sedangkan tertinggi pada pakan A (tepung usus ayam).

\section{Komposisi substrat media pemeliharaan}

Media pemeliharaan cacing berupa lumpur yang diambil dari lokasi yang sama dengan pengambilan cacing. Sebagian contoh substrat kemudian dianalisis komposisi substrat di laboratorium, hasil analisis substrat disajikan pada Tabel 2.

\section{Rekapitulasi data hasil penelitian}

Data hasil penelitian meliputi bobot ratarata awal dan akhir penelitian, pertumbuhan mutlak, laju pertumbuhan spesifik, sintasan, dan konversi pakan disajikan pada Tabel 3.

Tabel 2. Komposisi media pemeliharaan yang digunakan dalam penelitian

Table 2. Composition of culture media was used in the experiment

\begin{tabular}{lccl}
\hline \multicolumn{1}{c}{$\begin{array}{c}\text { Parameter } \\
\text { Parameters }\end{array}$} & $\begin{array}{c}\text { Satuan } \\
\text { Unit }\end{array}$ & $\begin{array}{c}\text { Lumpur } \\
\text { Mud }\end{array}$ & $\begin{array}{c}\text { Metode/alat } \\
\text { Method/tools }\end{array}$ \\
\hline $\begin{array}{l}\text { Karbon organik } \\
\text { Organic carbon }\end{array}$ & $\%$ & 2.26 & LPT. 2005. Spektro \\
$\begin{array}{l}\text { Total N } \\
\text { C/N ratio }\end{array}$ & $\%$ & 0.13 & LPT. 2005. Spektro \\
$\begin{array}{l}\text { Tekst ur fisik: } \\
\text { Physical text ure: }\end{array}$ & - & 17.38 & Perhitungan \\
$\quad$ - Pasir (Sand) & & & \\
$\quad$ - Debu (Loam) & $\%$ & 55.47 & Pipet (Pipette) \\
- Liat (Clay) & $\%$ & 35.14 & Pipet (Pipette) \\
\hline
\end{tabular}


Tabel 3. Rekapitulasi data hasil penelitian $(x \pm S D)$

Table 3. Research data agregation $(x \pm S D)$

\begin{tabular}{|c|c|c|c|c|}
\hline \multirow{2}{*}{$\begin{array}{l}\text { Parameter } \\
\text { Parameters }\end{array}$} & \multicolumn{4}{|c|}{ Perlakuan (Treatments) } \\
\hline & A & B & C & D \\
\hline $\begin{array}{l}\text { Bobot rata-rata awal }(\mathrm{g}) \\
\text { Average of initial weight }(\mathrm{g})\end{array}$ & $0.71^{\mathrm{a}} \pm 0.10$ & $0.70^{\mathrm{a}} \pm 0.09$ & $0.71^{\mathrm{a}} \pm 0.10$ & $0.67^{a} \pm 0.09$ \\
\hline $\begin{array}{l}\text { Bobot rata-rata akhir }(\mathrm{g}) \\
\text { Average of final weight }(\mathrm{g})\end{array}$ & $1.72^{\mathrm{a}} \pm 0.24$ & $1.01^{b} \pm 0.13$ & $1.46^{c} \pm 0.07$ & $1.30^{c} \pm 0.15$ \\
\hline $\begin{array}{l}\text { Pertumbuhan mutlak (g) } \\
\text { Absolute growth }(\mathrm{g})\end{array}$ & $1.01^{\mathrm{a}} \pm 0.24$ & $0.31^{b} \pm 0.15$ & $0.75^{c} \pm 0.10$ & $0.63^{c} \pm 0.16$ \\
\hline $\begin{array}{l}\text { Laju pertumbuhan spe sifik (\%/hari) } \\
\text { Spesific growth rate (SGR) (\%/day) }\end{array}$ & $1.76^{\mathrm{a}} \pm 0.36$ & $0.73^{b} \pm 0.37$ & $1.45^{a} \pm 0.27$ & $1.33^{c} \pm 0.35$ \\
\hline $\begin{array}{l}\text { Sintasan } \\
\text { Survival rate (SR) (\%) }\end{array}$ & $92.22^{\mathrm{a}} \pm 4.04$ & $80.56^{\mathrm{b}} \pm 1.36$ & $87.22^{a} \pm 9.05$ & $85.00^{\mathrm{a}} \pm 8.10$ \\
\hline $\begin{array}{l}\text { Konversi pakan } \\
\text { Feed conversion ratio }\end{array}$ & $0.65^{a} \pm 0.20$ & $1.63^{\mathrm{a}} \pm 0.83$ & $1.40^{\mathrm{a}} \pm 0.61$ & $1.43^{\mathrm{a}} \pm 1.01$ \\
\hline
\end{tabular}

Keterangan (Note):

Huruf yang berbeda dalam satu baris menunjukkan pengaruh berbeda nyata (anova, $\mathrm{P}<0,05)$ antar perlakuan. A : Tepung usus ayam, B : Tepung kepala udang, C : Tepung darah ayam, D : Pakan komersial (kontrol) (Different superscript letter in the same row shows significant difference (Anova, $P<0.05)$ among treatments. A : Intestine chicken powder, B : Shrimp head powder, C: Chicken blood powder, D : Commercial feed (control))

\section{Pertumbuhan mutlak}

Pertumbuhan mutlak merupakan selisih antara bobot akhir dan bobot awal cacing. Pada awal penelitian bobot awal cacing rata-rata 0,67-0,71 g dan bobot rata-rata cacing akhir penelitian berkisar 1,01-1,72 g (Tabel 3). Selama 50 hari pemeliharaan diperoleh pertambahan bobot berkisar antara 0,3-1,01 g. Pertumbuhan tertinggi diperoleh pada perlakuan $A$, sedangkan terendah pada perlakuan B. Hasil analisis ragam menunjukkan perbedaan jenis pakan menghasilkan pertumbuhan yang berbeda nyata $(P<0,05)$ antara perlakuan $B$ dengan $A, C$, dan $D$, tetapi perlakuan $C$ dengan $D$ tidak berbeda nyata ( $P>0,05)$ (Gambar 1).

Berdasarkan analisis korelasi Pearson's diperoleh nilai koefisien korelasi sebesar $-0,515$ antara kadar protein pakan dengan pertumbuhan cacing. Berdasarkan nilai (sig $<0,05)$ tersebut berarti terdapat hubungan antar kedua variabel. Hubungan antara kadar protein dan pertumbuhan bertanda negatif (-), yang menunjukkan pakan dengan kadar protein yang tertinggi menghasilkan pertumbuhan cacing terendah. Hal ini ditunjukkan pada perlakuan B (tepung kepala udang) menghasilkan pertumbuhan cacing terendah. Perlakuan A (tepung usus ayam) dengan kadar protein tertinggi kedua menghasilkan pertumbuhan tertinggi.

Berdasarkan Tabel 4 dapat dilihat hasil analisis korelasi Pearson's diperoleh nilai koefisien korelasi sebesar 0,748 antara kadar lemak pakan dengan pertumbuhan cacing. Berdasarkan nilai $(\mathrm{sig}<0,01)$ yang berarti terdapat hubungan yang sangat kuat antar kedua variabel. Jika dilihat dari besarnya koefisien korelasi Pearson's antara kadar protein dan lemak, nilai $R^{2}$ protein vs pertumbuhan $<\mathrm{R}^{2}$ lemak vs pertumbuhan. Dengan demikian kadar lemak pakan lebih besar mempengaruhi pertumbuhan cacing.

\section{Laju pertumbuhan spesifik}

Laju pertumbuhan spesifik (Spesific Growth Rate) merupakan kecepatan pertumbuhan seiring pertambahan waktu. Berdasarkan Gambar 2 hasil analisis ragam diketahui perlakuan B (pakan tepung kepala udang) 


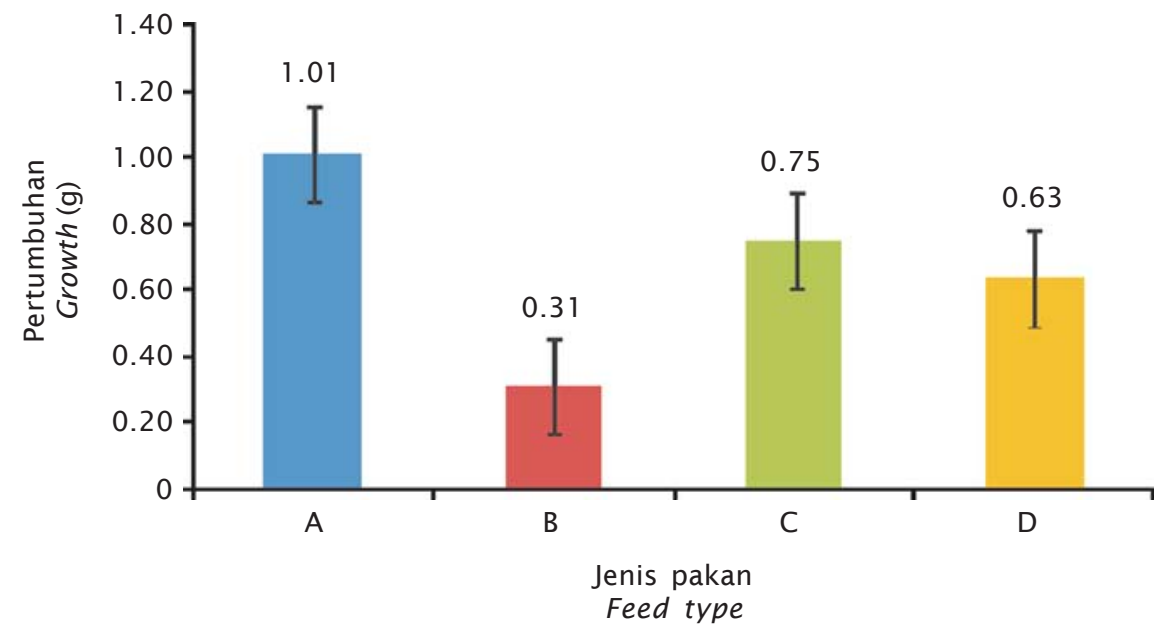

Keterangan (Note):

Huruf berbeda pada diagram batang menunjukkan beda nyata antar perlakuan $(P<0,05)$. A : Tepung usus ayam, B : Tepung kepala udang, C : Tepung darah ayam, D : Pakan komersial (kontrol) (Different superscript letter in the same row show significant difference (Anova, P<0.05) among treatment. A : Intestine chicken powder, B: Shrimp head powder, C: Chicken blood powder, D : Commercial feed (control))

Gambar 1. Pertumbuhan mutlak rata-rata cacing laut Nereis sp. selama penelitian

Figure 1. Average of absolute growth rate of marine worm Nereis sp. during experiment

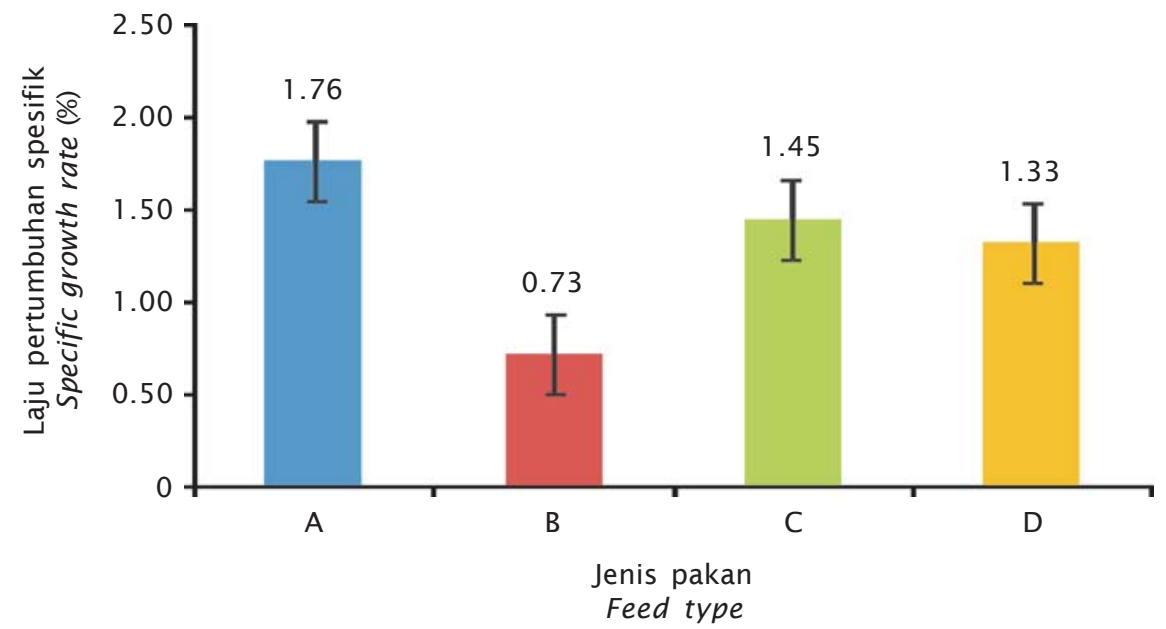

Keterangan (Note):

Huruf berbeda pada diagram batang menunjukkan beda nyata antar perlakuan $(P<0,05)$. A : Tepung usus ayam, B : Tepung kepala udang, C : Tepung darah ayam, D : Pakan komersial (kontrol) (Different superscript letter in the same row show significant difference (Anova, $P<0.05)$ among treatment. $A$ : Intestine chicken powder, $B$ : Shrimp head powder, C: Chicken blood powder, D : Commercial feed (control))

Gambar 2. Laju pertumbuhan spesifik rata-rata cacing laut Nereis sp. selama penelitian

Figure 2. Specific growth rate of marine worm Nereis sp. during the experiment 
memberikan pengaruh signifikan terendah $(P<0,05)$ terhadap laju pertumbuhan spesifik cacing antar perlakuan.

Untuk mengetahui hubungan kandungan nutrisi pakan yang diberikan terhadap laju pertumbuhan spesifik cacing dilakukan uji korelasi Pearson's. Berdasarkan Tabel 4, hasil analisis korelasi Pearson's diperoleh nilai koefisien korelasi sebesar -0,540 antara kadar protein pakan dengan laju pertumbuhan spesifik cacing. Berdasarkan nilai $(\mathrm{sig}<0,01)$ yang berarti terdapat hubungan yang kuat antar kedua variabel. Hubungan antara kadar protein dan pertumbuhan bertanda negatif (-), yang menunjukkan pakan dengan kadar protein yang tertinggi menghasilkan pertumbuhan cacing terendah. Hal ini ditunjukkan pada perlakuan B (tepung kepala udang) menghasilkan pertumbuhan cacing terendah. Perlakuan A (tepung usus ayam) dengan kadar protein tertinggi kedua menghasilkan pertumbuhan tertinggi.

Selanjutnya untuk mengetahui hubungan kadar lemak pakan yang diberikan terhadap laju pertumbuhan spesifik cacing juga dilakukan analisis korelasi. Berdasarkan Tabel 4 hasil analisis korelasi Pearson's diperoleh nilai koefisien korelasi sebesar 0,628 antara kadar lemak pakan dengan laju pertumbuhan spesifik cacing. Berdasarkan nilai (sig $<0,01$ ) yang berarti terdapat hubungan yang kuat antar kedua variabel.

\section{Sintasan}

Pada awal penelitian penebaran cacing masing-masing sebanyak 30 ekor/wadah. Pada akhir penelitian diketahui sintasan cacing laut rata-rata selama penelitian berkisar antara 80,56\%-92,22\%. Sintasan tertinggi diperoleh pada perlakuan $\mathrm{A}$, diikuti perlakuan C, D, dan terendah pada perlakuan B. Hasil analisis ragam menunjukkan perlakuan $B$ berbeda nyata terendah $(P<0,05)$ dengan perlakuan $A$, C, dan D (Gambar 3).

Berdasarkan analisis korelasi Pearson's diperoleh nilai koefisien korelasi sebesar 0,537 antara kadar lemak pakan dengan pertumbuhan cacing. Berdasarkan nilai (sig $<0,01$ ) yang berarti terdapat hubungan yang kuat antar kedua variabel.

Berdasarkan hasil analisis korelasi Pearson's antara kadar protein dan lemak terhadap parameter pertumbuhan, laju pertumbuhan spesifik, dan sintasan diperoleh nilai koefisien korelasi Pearson's masing-

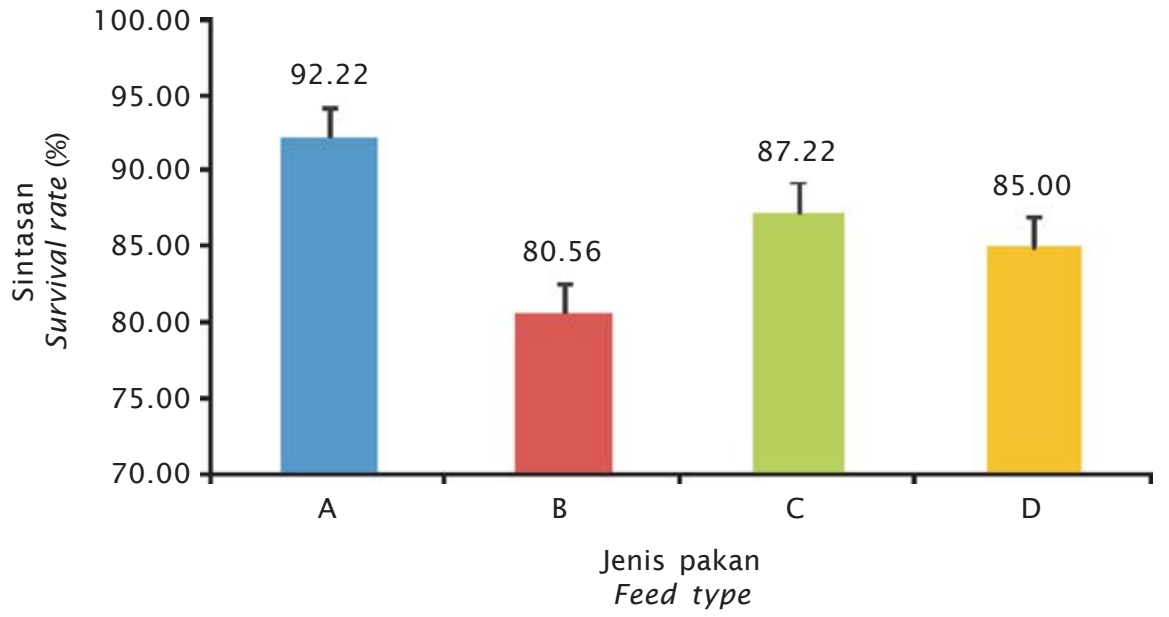

Keterangan (Note):

Huruf berbeda pada diagram batang menunjukkan beda nyata antar perlakuan $(P<0,05)$. A : Tepung usus ayam, B : Tepung kepala udang, C : Tepung darah ayam, D : Pakan komersial (kontrol) (Different superscript letter in the same row show significant difference (Anova, P<0.05) among treatment. A : Intestine chicken powder, B : Shrimp head powder, $C$ : Chicken blood powder, D : Commercial feed (control))

Gambar 3. Sintasan cacing laut Nereis sp. selama penelitian

Figure 3. Survival rate of marine worm Nereis sp. during the experiment 
Tabel 4. Nilai koefisien korelasi Pearson's antara kadar protein dan lemak pakan dengan masing-masing parameter

Table 4. Value of Pearson's correlation between protein and fat feed with parameters

\begin{tabular}{lcc}
\hline \multicolumn{1}{c}{ Parameter (Paramet ers) } & Prot ein & Lemak (Lipid) \\
\hline Pertumbuhan mutlak (Absolute weight) & $-0.515^{* *}$ & $0.748^{* * *}$ \\
Laju pertumbuhan spesifik (Spesific growth rate) & $-0.540^{* * *}$ & $0.628^{* * *}$ \\
Sintasan (S urvival rate) & -0.303 & $0.537^{* * *}$ \\
\hline
\end{tabular}

Keterangan (Note):

* $\mathrm{P}<0.05,{ }^{* *} \mathrm{P}<0.01$

masing parameter (Tabel 4). Berdasarkan Tabel 4 diketahui hubungan kadar protein lebih kecil dibandingkan hubungan kadar lemak dengan parameter pertumbuhan.

\section{Hubungan panjang-bobot}

Hubungan panjang-bobot masing-masing perlakuan disajikan pada Gambar 4-7. Berdasarkan Gambar 4-7, diketahui nilai koefisien korelasi $\left(R^{2}\right)$ semua perlakuan berkisar 0,461 0,616 . Nilai konstanta $b$ berturut-turut pada masing-masing perlakuan: C (tepung darah) sebesar 1,168; A (tepung usus ayam) sebesar 1,278; D (pakan komersial) sebesar 1,351; dan B (tepung kepala udang) sebesar 1,495. Jika diperhatikan berdasarkan nilai konstanta $b$ pada semua perlakuan menunjukan nilai $b<3$, yang berarti pertumbuhan bersifat allometrik (Durou et al., 2008). Menurut Lagler et al. (1977) dalam Effendie (1979), jika nilai $b<3$ berarti pertumbuhan panjang tidak seimbang daripada pertumbuhan bobotnya. Bila nilai $b=$ 3 maka pertumbuhan bobot seimbang dengan pertumbuhan panjang disebut isometric (Ricker dalam Effendie, 1979).

\section{Konversi pakan}

Konversi pakan (Feed Conversion Ratio) merupakan perbandingan antara jumlah makanan yang diberikan dengan pertambahan bobot, makin rendah nilai konversi pakan maka semakin efisien hewan itu mengubah makanan menjadi jaringan baru (Sudradjat, 2011). Konversi pakan berkisar 0,6-1,63; konversi pakan tertinggi pada perlakuan $B$, sedangkan terendah pada perlakuan A. Berdasarkan hasil analisis ragam pemberian jenis pakan berbeda memberikan pengaruh tidak berbeda nyata (Anova, P>0,05) terhadap konversi pakan cacing laut antar perlakuan (Gambar 8).

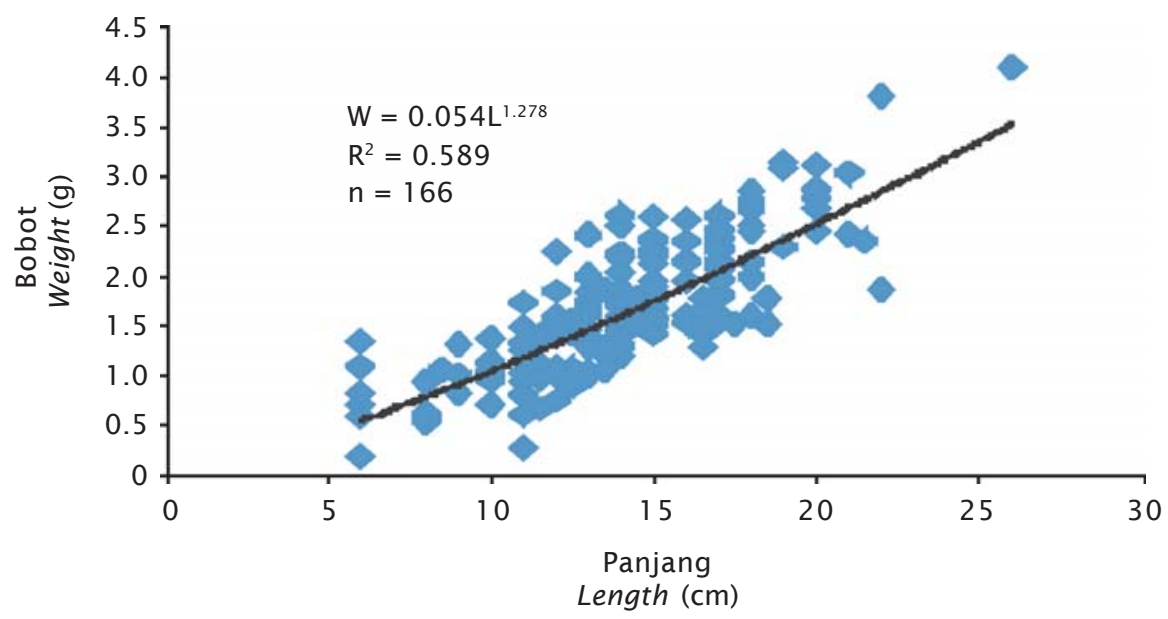

Gambar 4. Hubungan panjang-bobot cacing laut Nereis sp. (perlakuan A)

Figure 4. Relationship of length-weight of marine worm Nereis sp. (treatment A) 


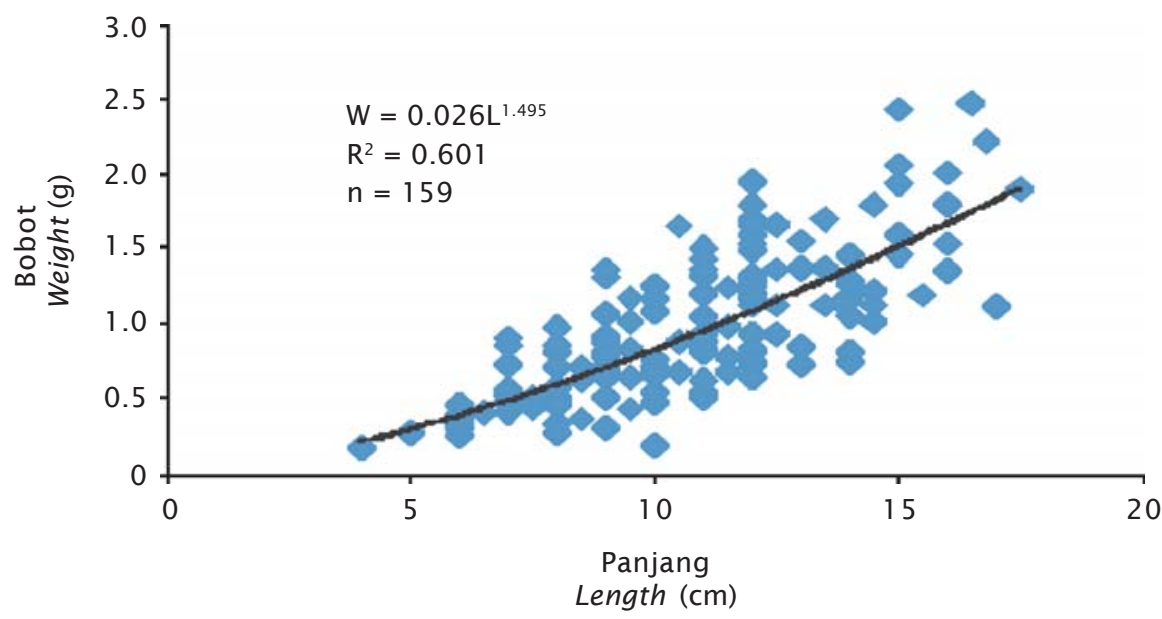

Gambar 5. Hubungan panjang-bobot cacing laut Nereis sp. (perlakuan B)

Figure 5. Relationship of length-weight of marine worm Nereis sp. (treatment B)

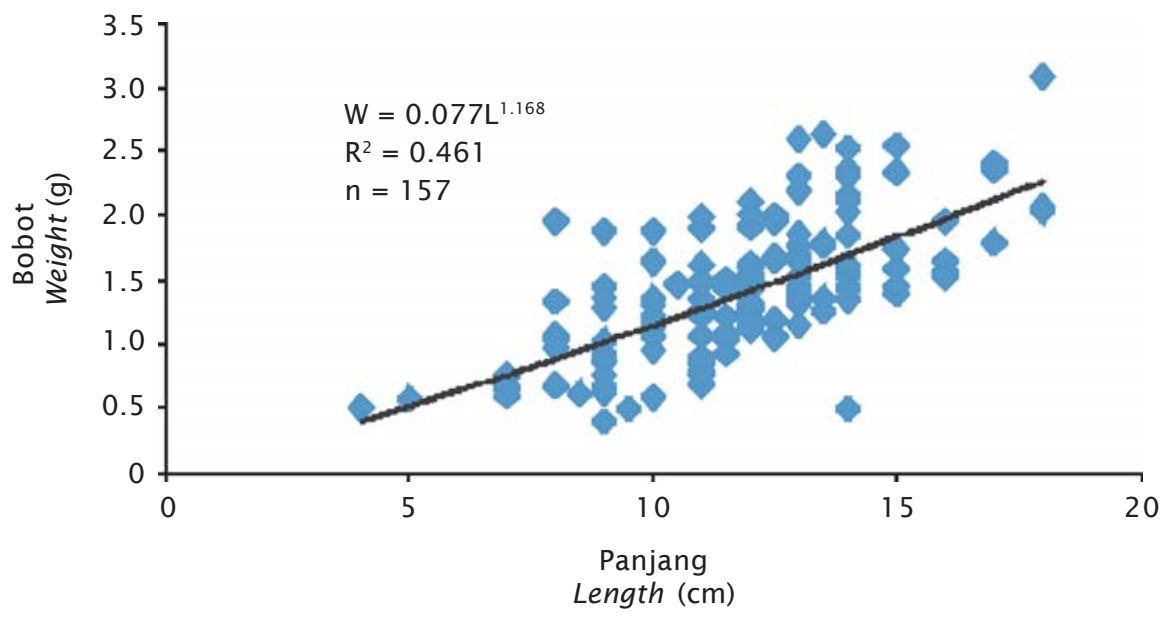

Gambar 6. Hubungan panjang-bobot cacing laut Nereis sp. (perlakuan C)

Figure 6. Relationship of length-weight of marine worm Nereis sp. (treatment C)

\section{Kualitas air}

Kisaran kualitas air selama penelitian disajikan pada Tabel 5. Berdasarkan Tabel 5, kualitas air selama pemeliharaan dapat diketahui suhu air berkisar $23,04^{\circ} \mathrm{C}-24,70^{\circ} \mathrm{C}$; salinitas 15-26,26 mg/L; DO 6,20-8,34 mg/L; dan $\mathrm{pH}$ berkisar 5,98-6,10. Kualitas air pada penelitian ini masih sesuai untuk kehidupan cacing laut berkisar $23^{\circ} \mathrm{C}-32^{\circ} \mathrm{C}$, dan salinitas 14-30\% (Yuwono et al., 1997).

Kisaran kualitas air pada penelitian ini lebih rendah jika dibandingkan dengan kisaran kualitas air pada pemeliharaan D. pinaticirris selama penelitian di laboratorium masingmasing parameter rata-rata suhu air $25^{\circ} \mathrm{C}$; salinitas 15\%; pH 6,5; dan $\mathrm{O}_{2}$ terlarut 6,9 mg/L (Wibowo, 2010).

Kelimpahan cacing laut ini sangat dipengaruhi kondisi lingkungan habitatnya baik substrat maupun kualitas airnya (Siregar, 2008). Kualitas substrat pada penelitian ini mempunyai tekstur pasir 55,47\%; debu $35,14 \%$; dan liat 9,39\%. Nereis sp. umumnya hidup di daerah estuarin dengan kondisi substrat lumpur berpasir, dangkal dan dipengaruhi arus 


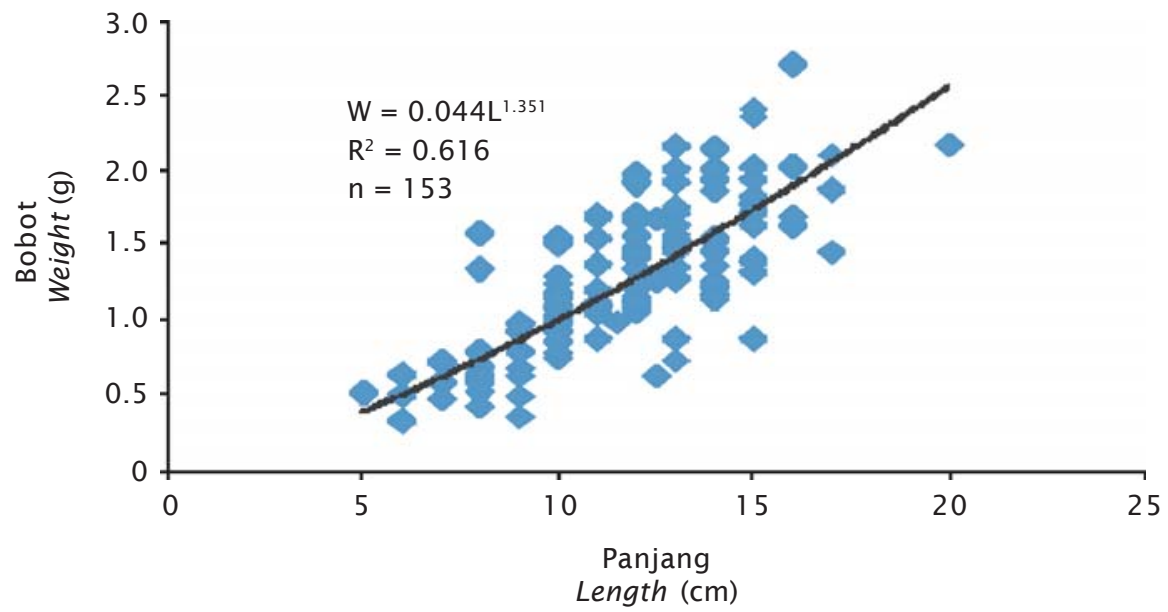

Gambar 7. Hubungan panjang-bobot cacing laut Nereis sp. (perlakuan D/kontrol)

Figure 7. Relationship of length-weight of marine worm Nereis sp. (treatment D/ control)

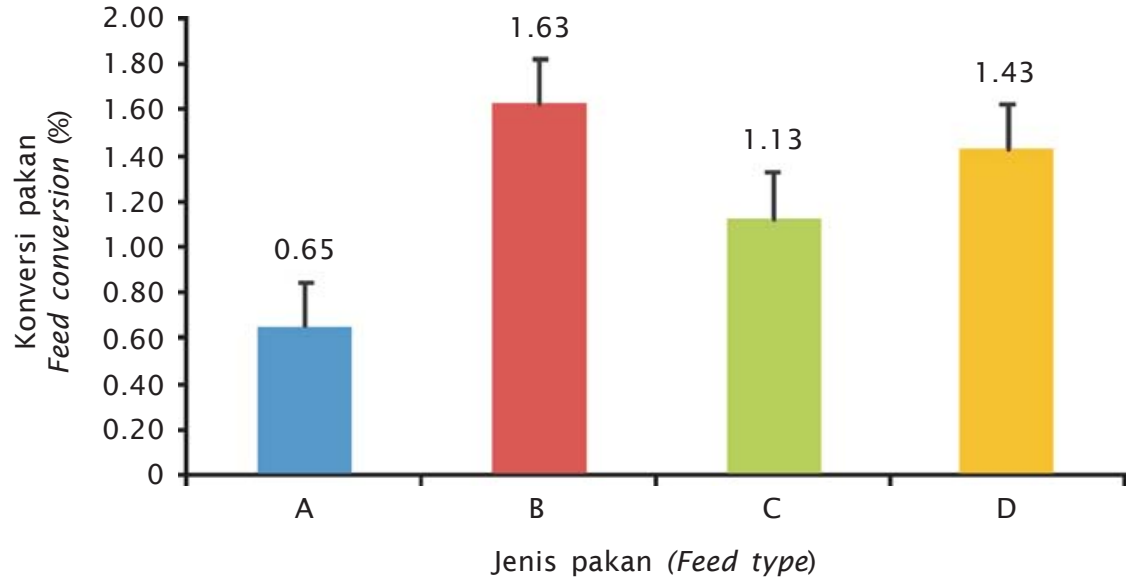

Keterangan (Note):

Huruf yang sama pada diagram batang menunjukkan tidak berbeda nyata antar perlakuan $(\mathrm{P}>0,05)$. A : Tepung usus ayam, $\mathrm{B}$ : Tepung kepala udang, $\mathrm{C}$ : Tepung darah ayam, D : Pakan komersial (kontrol) (The same superscript letter in the same row show no significant difference (Anova, $P<0.05$ ) among treatment. A : Intestine chicken powder, $B$ : Shrimp head powder, C: Chicken blood powder, D: Commercial feed (control))

Gambar 8. Konversi pakan rata-rata cacing laut Nereis sp. selama penelitian

Figure 8. Feed conversion marine worm Nereis sp. during experiment

pasang surut. Menurut Junardi (2001), substrat yang mengendap banyak mengandung bahan organik, berdasarkan warnanya semakin hitam biasanya akan semakin tinggi kandungan bahan organik. Bahan organik ini dimanfaatkan oleh organisme bentos termasuk Polychaeta di dasar perairan.

\section{BAHASAN}

\section{Kandungan Nutrisi Pakan Uji}

Kandungan nutrisi pakan uji yang digunakan dalam penelitian disajikan pada Tabel 1. Kadar protein pada penelitian ini 
Tabel 5. Kualitas air media pemeliharaan cacing selama penelitian

Table 5. Water quality of media culture worm in experiment

\begin{tabular}{lccccc}
\hline \multicolumn{1}{c}{$\begin{array}{c}\text { Parameter } \\
\text { Parameters }\end{array}$} & $\begin{array}{c}\text { Satuan } \\
\text { Unit }\end{array}$ & $\begin{array}{c}\text { Rataan } \\
\text { Average }\end{array}$ & Minimum & Maksimum & $\begin{array}{c}\text { Kisaran ideal } \\
\text { Ideal range }\end{array}$ \\
\hline Suhu (Temperature) & ${ }^{\circ} \mathrm{C}$ & 23.91 & 23.04 & 24.70 & $23-32$ \\
$\begin{array}{l}\text { Salinitas (Salinity) } \\
\text { Oksigen te rlarut }\end{array}$ & $\mathrm{mg} / \mathrm{L}$ & 18.72 & 15.00 & 26.26 & $14-30$ \\
$\begin{array}{l}\text { Dissolved oxygen } \\
\mathrm{pH}\end{array}$ & $\mathrm{mg} / \mathrm{L}$ & 6.94 & 6.20 & 8.34 & $0.80-9.30$ \\
\hline
\end{tabular}

berkisar 33,61\%-64,07\%; kadar lemak berkisar 0,41\%-35,63\% (bobot basah). Kadar protein tertinggi diperoleh pada jenis pakan B (tepung kepala udang), sedangkan terendah diperoleh pada perlakuan D (pakan komersial).

Hasil analisis proksimat tepung kepala udang mempunyai kadar protein sebesar $64,07 \%$; jika dibandingkan dengan perlakuan yang lain tepung kepala udang mempunyai kandungan protein tertinggi. Hal ini disebabkan tepung kepala udang mengandung kitin yang tinggi. Kitin merupakan senyawa polisakarida yang berasosiasi dengan protein sehingga pada proses analisis proksimat kadar protein pada tepung kepala udang tinggi, untuk memisahkan kandungan kitin dan protein diperlukan proses deproteinase (Toan, 2009).

Kadar protein dan lemak pada tepung usus ayam disebabkan oleh kandungan protein yang terdapat dalam usus ayam. Hal ini dapat dikaitkan dengan fungsi usus yang merupakan saluran pencernaan yang mempunyai kemampuan menyerap nutrisi dari pakan sebelum beredar ke seluruh badan, sehingga kandungan protein dan lemak banyak tersimpan di dalam usus.

Hasil analisis proksimat pada perlakuan C (tepung darah) diperoleh kadar protein sebesar $37,59 \%$ dan lemak sebesar 10,47\%. Jika dibandingkan dengan pakan komersial (kontrol), tepung darah mempunyai kadar protein dan lemak yang lebih tinggi. Hal ini disebabkan fungsi umum darah yang membawa nutrisi untuk diserap ke seluruh badan sehingga darah ayam mengandung kadar protein dan lemak yang cukup tinggi.

Kadar protein terendah diperoleh pada perlakuan D (pakan komersial) dibandingkan dengan yang lain. Hal ini menunjukkan kualitas pakan komersial belum tentu mempunyai kadar protein lebih tinggi dibandingkan dengan bahan baku lokal yang lain. Kadar protein yang tertulis di kemasan sebesar 35\%, berbeda dengan hasil analisis proksimat yang telah dilakukan sebesar 33,61\%.

Pakan uji yang diberikan pada penelitian ini mempunyai kadar protein yang lebih tinggi. Jika dibandingkan dengan kandungan protein pakan uji yang digunakan oleh Hartanti (2010) yang menggunakan serasah daun mangrove Arenicola marina sebesar $14,73 \%$ dan Rhizopora stylosa sebesar 3,39\%. Kadar protein pada penelitian ini juga lebih tinggi jika dibandingkan dengan kadar protein pakan uji berupa limbah pakan pada sistem resirkulasi yang dimanfaatkan sebagai untuk pakan Nereis virens dengan kadar protein sebesar 18,20\%52,78\% dan lemak 7,02-22,08 (Brown et al., 2011).

\section{Pertumbuhan Mutlak}

Berdasarkan Gambar 1 dapat diketahui jenis pakan A (tepung usus ayam) menghasilkan pertumbuhan tertinggi, sedangkan perlakuan B menghasilkan pertumbuhan terendah. Jika dibandingkan antara pakan $A$ dan $B$, komposisi nutrisi berupa kadar protein dan lemak jenis pakan A (tepung usus ayam) paling seimbang dibandingkan jenis pakan yang lain. Sebaliknya jenis pakan dari perlakuan B (tepung kepala udang) mempunyai komposisi yang tidak seimbang sehingga pertumbuhan cacing pada perlakuan $\mathrm{B}$ juga terendah. Menurut Prevedelli \& Vandinii (1997), hal ini disebabkan faktor komposisi pakan memegang peranan penting dalam pertumbuhan cacing Nereididae. Keseimbangan komposisi kandungan nutrisi antara protein dan lemak pada pakan yang diberikan mempengaruhi pertumbuhan (Prevedelli \& Vandini, 1997; Wibowo, 2010). 
Pertumbuhan terendah pada perlakuan B, jika dilihat dari hasil analisis proksimat jenis pakan tepung kepala udang mempunyai kadar protein sebesar $64,07 \%$ dan lemak sebesar $0,41 \%$. Jika dibandingkan dengan jenis pakan A, C, dan D, perlakuan B mempunyai kadar protein yang tertinggi, tetapi dalam penelitian ini menghasilkan pertumbuhan yang terendah. Hal ini disebabkan tepung kepala udang mengandung kitin yang tingkat kecernaannya rendah (Yulianingsih \& Teken, 2008), sehingga cacing laut mensintesis nutrisi dari tepung kepala udang tidak sebaik dibandingkan jenis pakan yang lain. Selain itu, pertumbuhan cacing pada perlakuan B lebih rendah dibandingkan dengan perlakuan yang lain disebabkan energi yang diperlukan untuk merombak protein lebih besar. Menurut Buwono (2000) dalam Wibowo (2010), katabolisme protein membutuhkan energi yang lebih besar (30\%) dalam proses penyerapannya sehingga pertumbuhan cacing pada perlakuan B lebih rendah dibandingkan perlakuan yang lain.

\section{Laju Pertumbuhan Spesifik}

Laju pertumbuhan spesifik cacing pada penelitian ini berkisar 0,73\%-1,76\%/hari. Nilai ini menunjukkan kecepatan pertumbuhan cacing laut selama penelitian. Laju pertumbuhan spesifik pada penelitian ini lebih tinggi jika dibandingkan hasil penelitian yang menggunakan 6 jenis pakan pada cacing $N$. diversicolor selama 60 hari menghasilkan laju pertumbuhan spesifik berkisar 0,053\%0,068\%/hari (Costa et al., 2000). Selain itu, laju pertumbuhan spesifik pada penelitian ini juga lebih tinggi jika dibandingkan hasil penelitian Wibowo (2010), laju pertumbuhan spesifik pada cacing lur yang dipelihara selama 60 hari berkisar 0,0313-0,0159\%/hari. Menurut Batista et al. (2003), kecepatan pertumbuhan dapat digunakan untuk mengetahui kualitas pakan. Dengan demikian dilihat dari nilai laju pertumbuhan spesifik menunjukkan pakan yang diberikan mempunyai kualitas lebih baik dibandingkan penelitian terdahulu. Hal ini disebabkan jenis pakan yang digunakan pada penelitian menggunakan bahan hewani yang lebih mudah dicerna oleh cacing (Yuwono et al., 2000).

Menurut Costa et al. (2000) pakan tunggal yang digunakan mampu mendukung kehidupan cacing $N$. diversicolor. Hal ini sesuai dengan hasil penelitian ini. Perlakuan A yang menggunakan tepung usus ayam menghasilkan laju pertumbuhan tertinggi dibandingkan perlakuan yang lain. Hal ini menunjukkan kandungan nutrisi tepung usus ayam dapat dimanfaatkan dengan baik sehingga cacing pada perlakuan A lebih cepat tumbuhnya dibandingkan dengan perlakuan yang lain. Laju pertumbuhan spesifik terendah pada perlakuan $B$, hal ini disebabkan cacing pada perlakuan B mempunyai pertambahan bobot terendah. Tepung kepala udang yang diberikan belum dapat mendukung pertumbuhannya. Hal ini berkaitan dengan kandungan kitin yang tinggi sehingga sukar dicerna dan membutuhkan energi lebih banyak sehingga pertumbuhannya lebih lambat dibandingkan dengan perlakuan yang lain.

Berdasarkan analisis korelasi Pearson's, hubungan kadar lemak pakan lebih besar mempengaruhi pertumbuhan, laju pertumbuhan spesifik, dan sintasan. Hal ini dapat dikaitkan dengan fungsi lemak sebagai sumber energi untuk pertumbuhan (Yuwono, 2005). Dengan demikian, kandungan lemak yang terdapat dalam pakan yang diberikan dapat dijadikan sebagai sumber energi untuk kehidupan cacing selama penelitian.

Berdasarkan analisis korelasi Pearson's, hubungan kadar protein pakan dengan parameter pertumbuhan, laju pertumbuhan spesifik dan sintasan menunjukkan arah yang negatif. $\mathrm{Hal}$ ini berkaitan dengan bahan baku pakan pada perlakuan B (tepung kepala udang) yang mempunyai kandungan protein tinggi tetapi juga mempunyai kandungan kitin yang tinggi (Suptijah et al., 2002 dalam Fauzi, 2005). Kitin merupakan faktor pembatas yang sukar dicerna Jaime-Ceballos et al., (2009), sehingga pada penelitian ini cacing yang diberi tepung kepala udang menghasilkan pertambahan bobot, laju pertumbuhan spesifik, dan sintasan terendah dibandingkan perlakuan yang lain.

\section{Hubungan Panjang Bobot}

Hubungan panjang bobot diperoleh nilai koefisien korelasi $(r)$ semua perlakuan berkisar $0,75-0,79$. Berdasarkan nilai koefisien korelasi (r) pada masing-masing perlakuan, menunjukkan terdapat hubungan positif antara panjang dan bobot badan cacing. Berdasarkan analisis varian perbedaan jenis pakan menghasilkan hubungan panjang bobot yang tidak berbeda nyata $(P>0,05)$ antar perlakuan yang diberikan. 
Nilai konstansta b cacing laut pada penelitian ini berkisar 1,224-1,495. Berdasarkan nilai konstanta $b<3$, dengan demikian hubungan panjang-bobot cacing pada penelitian ini mengikuti pola pertumbuhan eksponensial allometrik (Effendi, 1979). Hal ini sesuai dengan hasil penelitian Dorou et al. (2008) yang menyatakan pola pertumbuhan cacing $N$. diversicolor yang ditangkap dari alam dengan nilai konstanta $b<3$ yang berarti pertumbuhan cacing bersifat allometrik. Hubungan panjang-bobot diukur untuk mengetahui pola pertumbuhan yang dikaitkan dengan status lingkungan suatu populasi. Pada penelitian ini dilakukan skala laboratorium, di mana faktor lingkungan relatif sama sehingga hubungan panjang-bobot antar perlakuan relatif sama.

\section{Sintasan}

Tingkat sintasan atau sintasan pada penelitian ini berkisar $80,56 \%-92,22 \%$. Tingkat sintasan pada penelitian ini lebih tinggi jika dibandingkan pada Nereis virens yang menggunakan limbah pakan ikan sebagai pakan menghasilkan tingkat sintasan sebesar 45,2\%-87,2\% (Brown et al., 2011). Selain itu, hasil penelitian ini juga lebih baik, jika dibandingkan dengan cacing $N$. diversicolor yang diberi pakan kista artemia dengan sintasan 77,7\% (Costa et al., 2000). Hal ini menunjukkan pakan yang diberikan dalam penelitian ini mampu mendukung kehidupan cacing selama penelitian sehingga tingkat sintasan cacing selama penelitian relatif tinggi dibandingkan penelitian yang lain. Selain itu, dikarenakan pakan yang diberikan berasal dari hewani yang lebih mudah dicerna oleh cacing dibandingkan dengan bahan dari nabati (Yuwono, 2005).

Berdasarkan hasil analisis varian, perlakuan B (tepung kepala udang) menghasilkan sintasan yang berbeda nyata terendah dibandingkan jenis pakan yang lain. Hal ini menunjukkan tepung kepala udang yang diberikan belum dimanfaatkan dengan baik dibandingkan perlakuan yang lain. Sintasan cacing tertinggi pada perlakuan A (tepung usus ayam) menghasilkan sintasan terbaik dibandingkan perlakuan lain. Hal ini disebabkan jenis pakan tepung usus ayam mampu dimanfaatkan cacing sehingga sintasannya lebih tinggi.

Tingkat sintasan pada penelitian ini lebih rendah jika dibandingkan hasil penelitian pada cacing $N$. diversicolor yang diberi pakan komersial sebesar 95,3\%-99,3\% (Batista et al., 2003). Hal ini diduga disebabkan cacing yang digunakan dalam penelitian ini diperoleh dari alam sehingga memerlukan adaptasi dengan lingkungan dan jenis pakan yang baru.

Faktor media substrat juga berpengaruh terhadap sintasan cacing semua perlakuan, hal ini diduga disebabkan substrat yang digunakan pada penelitian ini mempunyai kandungan pasir yang tinggi sehingga cacing membutuhkan energi yang lebih besar untuk bergerak. Wibowo (2010) telah melakukan penelitian pada cacing lur dengan substrat dengan komposisi pasir yang lebih sedikit menghasilkan tingkat sintasan lebih baik dibandingkan media dengan komposisi substrat pasir yang lebih banyak.

Berdasarkan analisis korelasi Pearson's, kadar lemak pakan mempunyai hubungan yang positif dengan sintasan cacing laut. Kadar lemak yang tinggi sintasan juga tinggi. Sintasan tertinggi pada perlakuan A (tepung usus ayam) disebabkan kandungan lemak pada tepung usus ayam dapat dimanfaatkan dengan baik oleh cacing laut.

\section{Konversi Pakan}

Berdasarkan Gambar 8, diketahui nilai konversi pakan berkisar 0,65-1,63. Nilai konversi pakan tertinggi pada perlakuan B (tepung kepala udang), sedangkan terendah pada perlakuan A (tepung usus ayam). Konversi pakan pada perlakuan B (tepung kepala udang) sebesar 1,63 artinya untuk menghasilkan $1 \mathrm{~g}$ cacing diperlukan pakan sebesar 1,63 g. Pada perlakuan A (tepung usus ayam) diperoleh nilai konversi pakan sebesar 0,65 , artinya untuk menghasilkan bobot cacing $1 \mathrm{~g}$ diperlukan pakan sebesar $0,65 \mathrm{~g}$ tepung usus ayam. Dengan demikian dari segi efisiensi, pakan dari tepung usus ayam lebih efisien menghasilkan pertambahan bobot cacing. Jika dibandingkan antar perlakuan, pakan A mempunyai nilai konversi pakan terendah artinya tepung usus ayam lebih efisien jika dibandingkan perlakuan yang lain.

Hasil penelitian ini lebih baik jika dibandingkan dengan hasil penelitian Batista et al. (2003), yang menggunakan pakan komersial untuk pakan $N$. diversicolor diperoleh nilai konversi pakan sebesar 1,62 dan 1,89. Pada cacing Nereis virens yang diberi pakan limbah pakan dari budidaya ikan halibut diperoleh nilai 
konversi pakan sebesar 0,63-1,87 (Brown et al., 2011). Dilihat dari nilai konversi pakan, jenis pakan yang digunakan dalam penelitian ini relatif lebih efisien dibandingkan dengan pakan komersial yang digunakan pada penelitian terdahulu.

\section{KESIMPULAN \& SARAN}

\section{Kesimpulan}

Berdasarkan hasil penelitian dapat ditarik kesimpulan sebagai berikut:

1. Cacing laut Nereis sp. dapat memanfaatkan pakan tunggal yang digunakan dalam penelitian ini berupa tepung usus dan darah ayam serta tepung kepala udang.

2. Tepung usus ayam mempunyai kualitas lebih baik dibandingkan dengan jenis pakan yang lain. Hal ini dapat dilihat dari pertumbuhan dan laju pertumbuhan spesifik, sintasan cacing uji menunjukkan perbedaan yang nyata dibandingkan dengan perlakuan yang lain. Jenis pakan yang lain yaitu tepung kepala udang dan tepung darah juga mempunyai kualitas yang sama dengan pakan komersial sehingga dapat dijadikan alternatif pakan dalam budidaya cacing laut.

3. Pertumbuhan cacing Nereis sp. mengikuti pola pertumbuhan allometrik.

\section{Saran}

1. Beberapa jenis pakan antara lain tepung usus ayam, tepung darah, dan tepung kepala udang dapat dijadikan alternatif selain pakan komersial untuk budidaya cacing laut. Namun penggunaan bahanbahan tersebut sebaiknya dibuat formulasi dengan bahan pakan yang lain sehingga komposisi nutrisinya lebih baik.

2. Perlu diketahui faktor-faktor yang dominan yang dapat mempengaruhi pertumbuhan dan sintasan pada budidaya cacing laut.

3. Penelitian sebaiknya dilanjutkan ke penggunaan Polychaeta dan beberapa jenis pakan alami yang lain yang digunakan sebagai pakan induk udang.

\section{DAFTAR ACUAN}

Agbebi, O.T., Otubusin, S.O., \& Ogunleye, F.O. 2009. Effect of Different Levels of Substitution of Fishmeal with Blood Meal in Pelleted Feeds on Catfish Clarias
Gariepinus (Burchell, 1822) Culture in Net Cages. European Journal of Scientific Research, 31(1): 6-10.

Azwar, Z.I., Hadi, L.E., \& Djajasewaka, H. 2004. Analisis kebijakan pengembangan pakan buatan untuk menunjang program budi daya ikan berkelanjutan. Dalam: Sudradjat, A., E.S. Heruwati, \& B. Priono. (Eds.) 2004. Analisis kebijakan pembangunan perikanan budidaya. Badan Riset Kelautan dan Perikanan, Departemen Kelautan dan Perikanan, Jakarta, hlm. 91-105.

Batista, F.M., Costa, P.F., Ramos, A., Passos, A.M., Ferreira, P.P., \& Fonseca. 2003. Production of the ragworm Nereis diversicolor (O.F. Muller, 1776), fed with a diet gilthead seabream Sparatus auratus L., 1758: Survival, growth, feed utilization and oogenesis. Bulletin Internatinonal Eksperimental Oceanografi, 19(1-4): 447-451.

Bischoff, A.A., Fink, P., \& Waller, U. 2009. The fatty acid composition of Nereis diversicolor cultured in an integrated recirculated system: Possible implications for aquaculture. Aquaculture, 296: 271-276.

Brown, N., Eddy, S., \& Plaud, S. 2011 . Utilization of waste from a marine recirculating fish culture system as a feed source for the polychaete worm, Nereis virens. Aquaculture, 322-323: 177-183.

Coman, G.J., Arnold, S.J., Callaghan, T.R., \& Preston, N.P. 2007. Effect of two maturation diet combinations on reproductive performance of domesticated Penaeus monodon. Aquaculture, 263: 75-83.

Costa, P.F., Narciso, L., \& Cancela, L., \& Fonseca. 2000. Growth, survival and fatty acid profile of Nereis diversicolor (O.F. Müller, 1776) fed on six different diets. Bulletin of marine science, 67(1): 337-343.

Efendie, I.M. 1979. Metoda biologi perikanan. Yayasan Dewi Sri. Jakarta, iv+112 hlm.

Fauzi, A. 2005. Pengaruh pemberian kepala udang dalam ransum terhadap kandungan lemak dan kolesterol daging serta persentase organ dalam ayam broiler. Skripsi. Program Studi Ilmu Nutrisi dan Makanan Ternak. IPB Bogor, 68 hlm.

García-Alonso, J., Müller, C.T., \& Hardege, J.D. 2008. Influence of food regimes and seasonality on fatty acid composition in the ragworm. Aquatic biology, 4: 7-13.

Hariyadi, B. \& Yuwono, E. 1998. Penelitian pendahuluan kelulusan hidup dan pertumbuhan juvenil cacing lur (Nereis sp.) 
yang dipelihara dalam media dengan salinitas berbeda. Biosfera, 11:17-22.

Hartanti, N.U. 2010. Pertumbuhan dan sintasan cacing lur (Dendronereis pinaticirris) yang diberi pakan serasah mangrove. Tesis. Program Studi Biologi. Program Pascasarjana. Unsoed. Purwokerto, xvi + $66 \mathrm{hlm}$.

Ignatius, B. 2001. Spawning and larval rearing technique for tropical clownfish Amphiprion sebae under captive condition. Journal aquaculture Tropical, 16(3): 241-249.

Jaime-Ceballos, B.J., Fraga-Castro, I., GalindoLópez, J., \& Alvarez-Capote, J.S. 2009. Effect of shrimp head meal inclusion level in Litopenaeus schmitti juveniles diet. Rev. Investigation Marine, 30(1): 71-78.

Kian, A.Y.S., Mustafa, S., \& Rahman, R.A. 2004. Broodstock condition and egg quality in tiger prawn, Penaeus monodon, resulting from feeding bioencapsulated live prey. Aquaculture International, 12: 423-433.

Luis, O.J. \& Passos, A.M. 1995. Seasonal changes in lipid content and composition of the polychaete Nereis (Hediste) diversicolor. Comparative Biochemical Physiology, IIIB (4): 579-586.

Memon, A.J., Ikhwanudin, M., Talpur, A.D., Khan, M.I. Fariddudin, M.O., Safiah, J., \& Abol Munafi, A.B. 2012. To determine the efficiency of different fresh diet in improving the spermatophore quality of banana shrimp Penaeus merquensis (De man, 1888). Journal of Animal and Veterinery Advance, $11(9): 1,478-1,485$.

Meunpol, O., lam-Pai, S., Suthikrai, W., \& Piyatiratitivorakul, S. 2007. Identification of progesterone and $17 \alpha$ hydroxyprogesterone in polychaetes (Perinereis sp.) and the effects of hormone extracts on penaeid oocyte development in vitro. Aquaculture, 270: 485-492.

Meunpol, O., Meejing, P., \& Piyatiratitivorakul, S. 2005. Maturation diet based on fatty acid content for male Penaeus monodon (Fabricius) broodstock. Aquaculture Research, 36: 1,216-1,225.

Middleditch, B.S., Missler, S.R., Hines, H.B., Micvey, J.P., Brown, A., Ward, D.G., \& Lawrence, A.L. 1980. Metabolic profiles of penaid shrimp: Dietary lipids and ovarian maturation. Journal of chromatography, 195: 359-368.

Nguyen, D.H., Wouters, R., Wille, M., Vu Thanh, Kim Dong, T., Van Hao, N., \& Sorgeloos, P.
2009. A fresh-food maturation diet with an adequate HUFA composition for broodstock nutrition studies in black tiger shrimp Penaeus monodon (Fabricius, 1798). Aquaculture, 297: 116-121.

Nguyen, B.T., Koshio, S., Sayikama, K., Ishikawa, M., Yokoyama, S., \& Kader, M.A. 2011 . Effects of polychaete extracts on reproductive performance of kuruma shrimp, Marsupenaeus japonicus Bate.-Part II. Ovarian maturation and tissue lipid compositions, Aquaculture, doi: $10.1016 / \mathrm{j}$. aquaculture.2011.11.038.

Olive, P.J.W. 1999. Polychaete aquaculture and Polychaeta science: a mutual synergism. Hydrobiologia, 402: 175-183.

Prevedelli, D. \& Vandini, R.Z. 1997. Survival and growth rate of Perinereis rullieri (Polychaeta, Nereididae) under different salinities and diets, Italian Journal of Zoology, 64(2): 135-139.

Rachmansyah, Usman, Kabangga, N., \& Makmur. 2006. Penggunaan tepung silase usus ayam dalam pakan pembesaran ikan kerapu macan, Epinephelus fuscogattatus. Jurnal Riset Akuakultur, I(1): 87-96.

Sui, L.Y., Sun, H.X., Wu, X.G., Wille, M., Cheng, Y.X., \& Sorgeloos, P. 2011 . Effect of dietary HUFA on tissue fatty acid composition and reproductive performance of Chinese mitten crab Eriocheir sinensis $(H$. MilneEdwards) broodstock. Aquaculture International, 19: 269-282.

Safarik, M., Redden, A.M., \& Schreider, M.J. 2006. Density-dependent growth of the polychaete Diopatra aciculata. Scientia Marina, 70S3: 337-341.

Sudaryono, A., Hokey, M.J., Kailis, S.G., \& Evans, L.H. 1995. Investigation of alternative protein source practical diets for juvenile shrimp, Peneaus monodon. Aquaculture, 134: 313-323.

Sudradjat, A. 2011 . Glosarium akuakultur. CV. Yrama Widya. Bandung, vi+290 hlm.

Toan, N.V. 2009. Production of Chitin and Chitosan from Partially Autolyzed Shrimp Shell Materials. The Open Biomaterials Journal, 1:21-24.

Wibowo, E.S. 2010. Pertumbuhan, metabolisme, dan kandungan kimia tubuh cacing lur (Dendronereis pinaticirris) yang dipelihara dengan pakan dan substrat berbeda. Tesis. Program Studi Biologi. Tesis. Program Pascasarjana. Unsoed. Purwokerto, xvi + 82 hlm. 
Wilding, T.A., Kelly, M.S., \& Black, K.D. 2006. Alternative marine sources of protein and oil for aquaculture feeds: state of the art and recommendations for further research. The Crown Estate, $63 \mathrm{pp}$.

Wouters, R., Lavens, P., Nieto, J., \& Sorgeloos, P. 2001. Penaeid shrimp broodstock nutrition: an updated review on research and development. Aquaculture, 202: 1-21.

Yulianingsih, R. \& Teken, Y. 2008. Fermentasi tepung kepala udang dengan enzim kitinase. Buletin Teknisi Litkayasa Akuakultur, 7(1): 65-68.

Yuwono, E., Siregar, A.S., Haryadi, B., \& Sugiharto. 2000. Kelulusan Hidup dan Pertumbuhan Cacing Lur Dendronereis pinnaticirris (Polychaeta: Nereididae) yang dipelihara pada substrat dan Padat Pene- baran Berbeda. Makalah Seminar Nasional. ITS. Surabaya, $9 \mathrm{hlm}$.

Yuwono, E. 2003. Studi aspek fisiologi untuk aplikasi dalam budidaya cacing lur (Nereis sp.). Sains Akuatik, 6(3): 66-74.

Yuwono, E., Haryadi, B., Susilo, U., Sahri, A., \& Sugiharto. 2002. Fertilisasi serta pemeliharaan larva dan juvenil sebagai upaya pengembangan teknik budidaya cacing lur. Biosfera, 19(3): 20-26.

Yuwono, E. 2005. Kebutuhan nutrisi Crustacea dan potensi cacing lur (Nereis, Polychaeta) untuk pakan udang. Jurnal Pembangunan Pedesaan, V(1): 42-49.

Yuwono, E., Sahri, A., \& Nganro, N.R. 1998. Aktivitas neuroendokrin dan kontrol endokrin reproduksi Nereis sp. Biosfera, 9: 1-8. 